\title{
Bioconversion performance and development of black soldier fly (Hermetia illucens L.) on treated cocoa pod husk
}

\author{
Keragaan biokonversi dan perkembangan lalat tentara hitam \\ (Hermetia illucens L.) pada kulit buah kakao yang diperlakukan
}

Ciptadi Achmad YUSUP*), Haryo Tejo PRAKOSO, SISWANTO \& Deden Dewantara ERIS

Indonesian Research Institute for Biotechnology and Bioindustry, Jalan Taman Kencana No. 1. Bogor 16128, Indonesia

Diterima tgl 22 Februari 2020 / disetujui tgl 6 April 2020

\begin{abstract}
Abstrak
Indonesia merupakan produsen kakao terbesar ketiga di dunia, sehingga jumlah kulit buah kakao (KBK) yang dihasilkan sangat melimpah. Untuk menangani limbah ini petani biasanya memanfaatkan KBK sebagai pakan untuk ruminansia kecil, namun praktik ini kurang efektif karena KBK memiliki kandungan protein yang rendah dan mengandung banyak lignin. Larva lalat tentara hitam (black soldier fly, BSF) (Hermetia illucens L.) (Diptera: Stratiomyidae) dikenal sebagai agen biokonversi yang dapat mencerna berbagai substrat organik dan sumber protein yang tinggi. Tujuan penelitian ini adalah mengevaluasi potensi penggunaan larva BSF untuk mengkonversi KBK berdasarkan parameter laju pertumbuhan relatif (LPR), efisiensi konversi makanan yang terserap (EKT), indeks reduksi limbah (IRL) dan waktu perkembangan. Ukuran tubuh imago dari masing-masing perlakuan juga diukur. Larva diberi pakan KBK segar (S), KBK segar yang dihancurkan (H), kompos $K B K(K)$, campuran KBK segar dan sampah makanan $(S+S M)$ dan campuran kompos KBK dan sampah makanan $(K+S M)$. Perlakuan sampah makanan juga diberikan sebagai kontrol. Perlakuan paling ideal untuk diterapkan di perkebunan kakao adalah $K+S M$ dengan hasil rata-rata bobot prapupa segar sebesar 11,20 g/100 larva dengan waktu perkembangan 18 hari. Perlakuan ini memiliki nilai IRL dan LPR terbaik dibandingkan dengan seluruh perlakuan. Kompos KBK yang dicampurkan dengan sampah makanan menghasilkan waktu perkembangan larva BSF yang lebih singkat.
\end{abstract}

[Kata kunci: EKT, LPR, waktu perkembangan, IRL, protein pakan alternatif]

*) Penulis korespondensi: c.a.yusup@iribb.org/ ciptadi.a.yusup@gmail.com

\begin{abstract}
Indonesia is the third largest cocoa producer in the world, thus the number of cocoa pod husk $(\mathrm{CPH})$ resulted from this activity is abundant. To handle this waste, farmer usually uses it directly as a feed source to small ruminants but this practice is less effective due to its low protein content and it also contains a substantial amount of lignin. Black Soldier Fly (BSF) (Hermetia illucens L.) (Diptera: Stratiomyidae) larvae are known as bioconversion agents that can be fed upon various organic substrates and they are also high protein source. The aim of this research was to evaluate the possibility of BSF grown on $\mathrm{CPH}$ based on their relative growth rate (RGR), efficiency of conversion of ingested food (ECI), waste reduction index (WRI), and development time. Body size of the imago from each treatment was also measured. Larvae were fed with fresh CPH (F), fresh blended CPH (B), composted CPH (C), mix of fresh $\mathrm{CPH}$ with food waste $(\mathrm{F}+\mathrm{FW})$ and mix of composted $\mathrm{CPH}$ with food waste $(\mathrm{C}+\mathrm{FW})$. Food waste served as a control. The results of this study show that the most ideal treatment that possible to be applied in cocoa plantation was $\mathrm{C}+\mathrm{FW}$ treatment which gave average prepupal fresh weight of $11.20 \mathrm{~g} / 100$ larvae with 18 days of development time. This treatment had the highest value of WRI and RGR among all treatments. Composted CPH that mixed with food waste treatment also had a shorter development time of BSF larvae.
\end{abstract}

[Keywords: ECI, RGR, development time, WRI, alternative protein feed]

\section{Introduction}

Cocoa pod husk (CPH) generated from harvested cocoa bean is considered as agricultural waste. As Indonesia is the third largest cocoa producer in the world (Gunawan \& Talib, 2017), the number of $\mathrm{CPH}$ resulted from cocoa production activity is abundant, especially in Sulawesi, where most of the cocoa in Indonesia is planted on this region. 
According to BPS (2017), CPHs in Sulawesi were generated as much as 402,100 tons in 2016 and it accounted for $61.19 \%$ nationwide. Methods by far to handle this waste are composting it or using it directly as a feed source to small ruminants. The last method is still considered less optimal when used as feed because low protein and high lignin content (Laconi \& Jayanegara, 2015).

The other way that may help CPH being used in feed industries is by using a bioconversion agent. Black Soldier Fly (BSF) (Hermetia illucens L.) (Diptera: Stratiomyidae) larvae are known to be the bioconversion agent that can be fed upon various organic substrates, such as manure (Cockcroft, 2018; Rehman et al., 2017), organic waste (Spranghers et al., 2017), and various type of agricultural wastes (Manurung et al., 2016; Supriyatna et al., 2016). They can convert these wastes into a significant amount of protein biomass, as high as 40\% (Elwert et al., 2010; Finke, 2013; Jayanegara et al., 2017). As they reach the adult stage as a fly, they are not a vector which can transmit disease because they do not have a mouthpart (Müller et al., 2017). Furthermore, they can reduce a significant amount of bacteria that pose a threat to human health when they feed on organic substrates that contain a high amount of bacteria such as manure (Lalander et al., 2013). Therefore, larvae are a promising bioconverter agent that can be further processed as a protein source.

To the best our knowledge, the studies about BSF grown on $\mathrm{CPH}$ media have never been reported. Concerned is taken pertaining to the significant amount of lignin that constructs $12 \%$ of CPH (Sutikno, 1997). Manurung et al. (2016) have tried to grow BSF larvae on rice straw which contained a moderate amount of lignin and found that the development time of BSF larvae was two times longer compares to when they were fed on restaurant or vegetable wastes. Therefore, $\mathrm{CPH}$ needs to be treated first before being given to BSF larvae. The treatments include reduce the $\mathrm{CPH}$ size by chopping and degrade the lignin of $\mathrm{CPH}$ using Promi $^{\circledR}$, a decomposing agent that contain Pholiota sp. which has ligninolytic enzymes. This study aimed to investigate various $\mathrm{CPH}$ treatments on its effect towards development time, waste reduction index, relative growth rate, the efficiency of conversion of ingested food, and morphological image on BSF.

\section{Materials and Methods}

\section{BSF maintenance and cultivation}

Five (5) g egg of BSF was placed on a wiremesh that placed $5 \mathrm{~cm}$ above chicken feed with $70 \%$ humidity. After several days, eggs will hatch and turn into larvae. The larvae will fall into chicken feed, feeding it until 5 days after hatching. After 5 days, in an early cultivating container, the larvae were then selected based on instar and moved into a new container. Mature larvae were grown in 2 weeks and continued to grow to prepupal stages. Then, the larvae would look for a dry place for pupation. About $10 \%$ population of prepupal were moved into a new container contained with wood dust for pupation and became imago. While another $90 \%$ population were used as a protein source in feed formulation.

Pre-pupae larvae stored in a container were moved into insectarium made from muslin cloth sized $3 \mathrm{~m} \times 3 \mathrm{~m} \times 3 \mathrm{~m}$. Adult BSF emerged from pupa after 10 days. Broadleaf plants were placed in insectarium as a medium for a mating area. Adult BSF would mate after 3-4 days after emerging from pupae. In order to make the adult BSF laying their egg in one area, pieces of dry wood were used. Two wood pieces were stacked together with a $0.2 \mathrm{~cm}$ gap in-between. The pieces then placed above the container covered by muslin cloth that contained food waste as an attractant.

\section{Cocoa pod husk composting}

$\mathrm{CPH}$ was composted using decomposer which consisted of Trichoderma sp., Aspergillus niger, and Pholiota sp. commercially known as Promi ${ }^{\circledR}$ (1 kg Promi ${ }^{\circledR}$ per ton CPH). Promi ${ }^{\circledR}$ was mixed in 200 liters of water and stirred before being sprayed into $\mathrm{CPH}$. The $\mathrm{CPH}$ was then mounded and covered with tarpaulin. The incubation period was 3 weeks. Mature compost was indicated by its darkened colour and it was easy to tear.

\section{BSF larvae feeding treatment}

There were six treatments tested to BSF larvae. Treatments were fresh chopped $\mathrm{CPH}$, blended $\mathrm{CPH}$ and chopped $\mathrm{CPH}$ that has been composted. Other treatments were food waste, the combination of food waste and composted cocoa pod husk, and the combination of food waste and fresh cocoa pod husk. The six treatments tested are explained in Table 1.

A hundred larvae were used for each treatment according to Manurung et al. (2016) and fed with $100 \mathrm{mg} /$ individual/day (about $10 \mathrm{~g} /$ container/ day). Every 3 days, the feed was changed with a new one to replace the old one resulted in about $30 \mathrm{gr} / 3$ days cycle.

The cultivating container used in this experiment was a jam bottle covered with gauze. Provision of feed was done at the beginning by storing the remaining feed in the refrigerator to avoid decomposition (specifically for the treatment of fresh CPH feed). There were three replications in each treatment so that there was a total of $18 \mathrm{jam}$ bottles. 
Table 1. Treatments of CPH tested

Tabel 1. Perlakuan KBK yang diuji

\begin{tabular}{|c|c|}
\hline Treatment/ Perlakuan & Note/ Keterangan \\
\hline Control / Kontrol & $\begin{array}{l}\text { Larvae were fed with food waste from the beginning until the trial period } \\
\text { ends. } \\
\text { Larva diberi pakan sampah makanan dari awal hingga akhir percobaan. }\end{array}$ \\
\hline $\begin{array}{l}\text { Composted }(\mathrm{C}) / \\
\text { Kompos }(K)\end{array}$ & $\begin{array}{l}\text { Larvae were fed with composted } \mathrm{CPH} \text { from the beginning until the trial } \\
\text { period ends. } \\
\text { Larva diberi pakan kompos KBK dari awal hingga akhir percobaan. }\end{array}$ \\
\hline $\begin{array}{l}\text { Fresh }(\mathrm{F}) / \\
\operatorname{Segar}(S)\end{array}$ & $\begin{array}{l}\text { Larvae were fed with fresh } \mathrm{CPH} \text { from the beginning until the trial period } \\
\text { ends. } \\
\text { Larva diberi pakan KBK segar dari awal hingga akhir percobaan. }\end{array}$ \\
\hline $\begin{array}{l}\text { Composted }+ \text { food waste }(\mathrm{C}+\mathrm{FW}) / \\
\text { Kompos }+ \text { sampah makanan }(K+S M)\end{array}$ & $\begin{array}{l}\text { First, larvae were fed with food waste for } 6 \text { days then fed with composted } \\
\text { CPH until the trial period ends. } \\
\text { Larva diberi pakan sampah makanan pada } 6 \text { hari pertama dan dilanjutkan } \\
\text { dengan pakan kompos KBK hingga akhir percobaan. }\end{array}$ \\
\hline $\begin{array}{l}\text { Fresh }+ \text { food waste }(\mathrm{F}+\mathrm{FW}) / \\
\text { Segar }+ \text { sampah makanan }(S+S M)\end{array}$ & $\begin{array}{l}\text { First, larvae were fed with food waste for } 6 \text { days then fed with fresh } \mathrm{CPH} \\
\text { until the trial period ends. } \\
\text { Larva diberi pakan sampah makanan pada } 6 \text { hari pertama dan dilanjutkan } \\
\text { dengan pakan KBK segar hingga akhir percobaan. }\end{array}$ \\
\hline $\begin{array}{l}\text { Blended (B) / } \\
\text { Hancur }(H)\end{array}$ & $\begin{array}{l}\text { The feed is in the form of fresh cocoa pod husk that blended resulted in a } \\
\text { smooth texture, then it was fed to larvae from the beginning until the trial } \\
\text { period ends. } \\
\text { Pakanf berupa KBK segar yang dihancurkan hingga teksturnya halus dan } \\
\text { diberikan pada larva dari awal hingga akhir percobaan. }\end{array}$ \\
\hline
\end{tabular}

Determination of development time, waste reduction index (WRI), efficiency of conversion of ingested food (ECI) and relative growth rate (RGR) of $B S F$

Development time of BSF larvae was observed starting from one-day-old of $1^{\text {st }}$ instar until $50 \%$ of population turned into prepupal stage on each treatment (observation ended). The WRI, ECI, and RGR values of BSF larvae were estimated according to Manurung et al. (2016) and Oonincx et al. (2015). To determine waste reduction index (WRI) value, the remaining feed was replaced every three days and BSF larvae were transferred to new jam bottles containing new feed but it was still the same treatment. The remaining feed obtained was then weighed to calculate the weight of the wet residue. The WRI was obtained by using formulas (Diener et al., 2009):

$$
\begin{aligned}
\mathrm{WRI} & =(\mathrm{D} / \mathrm{T}) \times 100 \\
\mathrm{D} & =(\mathrm{W}-\mathrm{R}) / \mathrm{W}
\end{aligned}
$$

$\mathrm{D}=$ Overall feed degradation $(\mathrm{g})$

$\mathrm{T}=$ Experiment duration (days)

$\mathrm{W}=$ Total weight of feed given $(\mathrm{g})$

$\mathrm{R}=$ Total residue during the experiment $(\mathrm{g})$

The relative growth rate was calculated using the formula:

$$
\mathrm{RGR}=\left[\left(\mathrm{W}_{2}-\mathrm{W}_{1}\right) / \mathrm{W}_{1}\right] /\left(\mathrm{T}_{2}-\mathrm{T}_{1}\right)
$$

$\mathrm{W} 2=$ Final total fresh weight $(\mathrm{g})$

$\mathrm{W} 1=$ Initial total fresh weight $(\mathrm{g})$

$\mathrm{T} 2=$ Last observation day (days)

$\mathrm{T} 1$ = Initial observation day (days)
The efficiency of conversion of ingested food (ECI) percentage was calculated using the formula:

$$
\mathrm{ECI}=[(\mathrm{W} 2-\mathrm{W} 1) /(\mathrm{W}-\mathrm{R})] \times 100 \%
$$

\section{Observation of BSF's imago body size}

The size of larvae is influenced by their feed. The anatomy of BSF grown on $\mathrm{CPH}$ as a diet was determined by using Leica M205C stereo microscope.

\section{Results and Discussion}

\section{Feeding option and BSF growth traits}

Black soldier larvae fed with food waste (control) had the highest prepupal fresh weight with average $15.47 \mathrm{~g} / 100$ larvae with 21 days of development time. Replacing the feed with several $\mathrm{CPH}$ treatments produced lower prepupal weight (under $12 \mathrm{~g} / 100$ larvae) and longer development time to above 40 days (Figure 1). The most ideal treatment that possible to be applied in the cocoa plantation was to mix the feed for BSF larvae with a food waste for the first 6 days ( $2^{\text {nd }}$ instar larva) and replaced the feed with composted $\mathrm{CPH}$ afterwards. The result showed that the combination of food waste and composted $\mathrm{CPH}(\mathrm{C}+\mathrm{FW})$ gave prepupal fresh weight of $11.20 \mathrm{~g} / 100$ larvae and development time of 18 days. This result was in line with Booth \& Sheppard (1984) that reported BSF larvae to require a high protein and easy-todigested feed for $1^{\text {st }}$ and $2^{\text {nd }}$ instar, and food waste 
has a higher protein than $\mathrm{CPH}$. This condition occurs due to the little size of the mandible of $1^{\text {st }}$ and $2^{\text {nd }}$ instar larvae. Development time of BSF larvae tends to be affected by feed types. Higher protein content provides shorter developing time. Different treatments of $\mathrm{CPH}$ also affected the development time of BSF larvae. Composted $\mathrm{CPH}$ seemed to be more acceptable for larvae compared to fresh $\mathrm{CPH}$ even it was blended. Alemawor et al. (2009) reported that $\mathrm{CPH}$ composted with Pleurotus ostreatus contains more crude protein compared to fresh $\mathrm{CPH}$, and protein content was increasing along with the duration of composting. This result indicated composting treatment was the best and applicable option to optimize $\mathrm{CPH}$ as a BSF feed.

Different feeding treatments affected the waste reduction index (WRI) of BSF larvae. Generally, food waste treatment produced higher reduction index (WRI), higher relative growth rate (RGR) and efficiency of conversion of ingested food (ECI) (Table 1). Control treatment showed higher RGR value that indicated shorter development time and consumed more feed as high as its WRI value. BSF larvae were also more efficient to convert food waste into its biomass compared to CPH's treatment. Higher protein content on food waste was required by BSF larvae to develop and gain their body mass with a conversion of glucose (Zheng et al., 2012). The C+FW treatment has a slightly shorter BSF's life cycle than control. The
$\mathrm{C}+\mathrm{FW}$ and $\mathrm{F}+\mathrm{FW}$ treatment has a similar RGR value to control until day 6 of observation but starting to decrease after. This is due to feed replacement with $\mathrm{CPH}$ after day 6 . However, all RGR value tends to decrease after day 9 except for $\mathrm{S}$ treatment that has the longest developmental time (51 days) (Figure 2). The treatment $\mathrm{C}+\mathrm{FW}$ has the highest overall RGR and WRI value among all treatment (Table 2). This condition indicated that $\mathrm{C}+\mathrm{FW}$ treatment produced a less residue of feed compared to other treatments, but due to the lower nutrition content of composted $\mathrm{CPH}$ resulted in the lower RGR and ECI value compared to control. Lower RGR value on protein-lack feed means BSF larvae adjust their energy budget and prioritize the allocation of their energy to growth and metabolism (Glazier, 2002; Hou, 2014; Manurung et al., 2016). This condition force BSF larvae to have a longer development time with a lower body mass. Glazier (2002) reported that the addition of some sugar and hydrolytic enzyme may increase the RGR and ECI values. However, it would not be applicable to most cocoa farmers in Indonesia. The $\mathrm{C}+\mathrm{FW}$ treatment provided a higher bioconversion rate that can be applied in the cocoa plantation with acceptable RGR and ECI values. The combination of composted $\mathrm{CPH}$ and food waste can solve the lack of protein and also shorten the BSF life cycle. Food waste can be provided from a cocoa farmer's household waste without any additional costs.

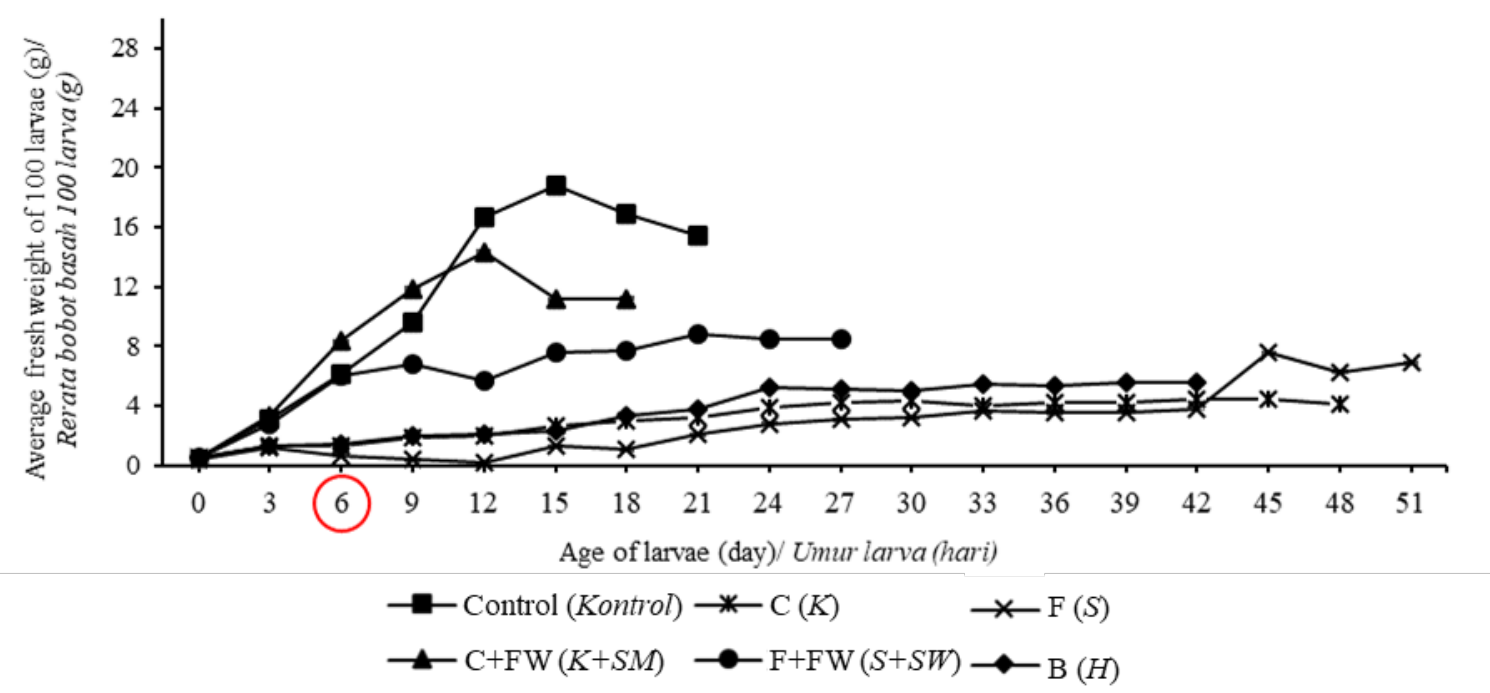

Figure 1. Development time of BSF larvae until pre-pupae stage fed with various CPH treatments. The treatments were food waste (control), composted $(\mathrm{C})$, fresh $(\mathrm{F})$, composted + food waste $(\mathrm{C}+\mathrm{FW})$, fresh + food waste $(\mathrm{F}+\mathrm{FW})$, and blended $\mathrm{CPH}(\mathrm{B})$. Food waste in $\mathrm{C}+\mathrm{FW}$ and $\mathrm{F}+\mathrm{FW}$ treatment were given at the beginning of the experiment until day 6 (marked with a red circle). Standard Errors are not seen in the graph because all of the values are below 0.1 .

Gambar 1. Waktu perkembangan larva BSF hingga stadia prepupa yang diberi pakan perlakuan KBK. Perlakuan sampah makanan (kontrol), kompos (K), segar $(S)$, kompos + sampah makanan $(K+S M)$, segar + sampah makanan $(S+S M)$ dan KBK hancur $(H)$. Sampah makanan pada perlakuan $K+S M$ dan $S+S M$ diberikan pada 6 hari pertama (ditandai dengan lingkaran merah). Standar eror tidak terlihat pada grafik karena seluruh nilai dibawah 0,1. 


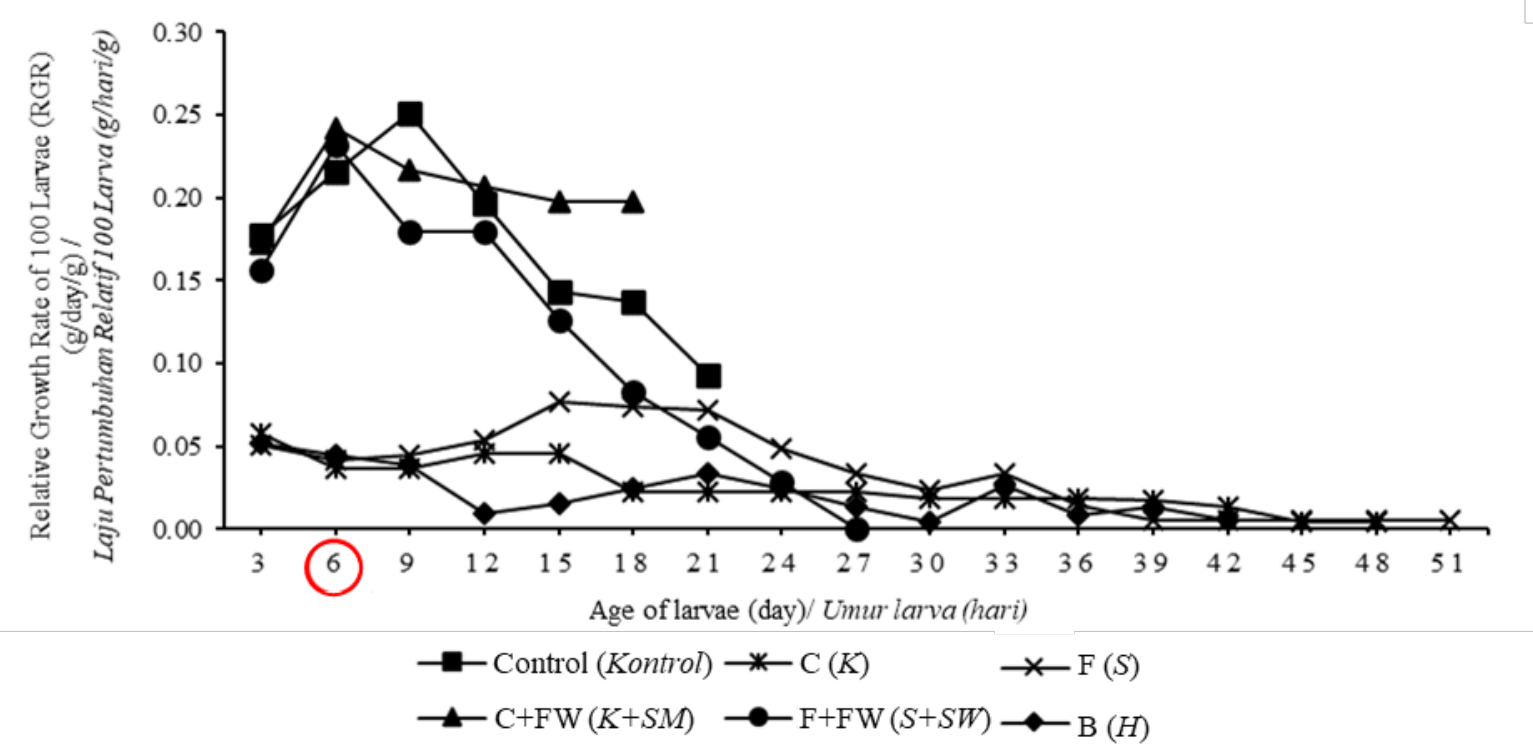

Figure 2. Relative growth rate of BSF larvae fed with various $\mathrm{CPH}$ treatments. The treatments were food waste (control), composted $(\mathrm{C})$, fresh $(\mathrm{F})$, composted + food waste $(\mathrm{C}+\mathrm{FW})$, fresh + food waste $(\mathrm{F}+\mathrm{FW})$, and blended $\mathrm{CPH}(\mathrm{B})$. Food waste in $\mathrm{C}+\mathrm{FW}$ and $\mathrm{F}+\mathrm{FW}$ treatment were given at the beginning of the experiment until day 6 (marked with a red circle).

Gambar 2. Laju pertumbuhan relatif larva BSF yang diberi pakan perlakuan KBK. Perlakuan sampah makanan (kontrol), kompos $(K)$, segar (S), kompos + sampah makanan $(K+S M)$, segar + sampah makanan $(S+S M)$ dan KBK hancur $(H)$. Sampah makanan pada perlakuan $K+S M$ dan $S+S M$ diberikan pada 6 hari pertama (ditandai dengan lingkaran merah).

Table 2. The average values of waste reduction index (WRI), relative growth rate (RGR) and efficiency of conversion of ingested food (ECI) (100 larvae).

Tabel 2. Nilai rata-rata indeks reduksi limbah (IRL), laju pertumbuhan relatif(LPR) dan efisiensi konversi makanan yang tercerna (EKT) (100 larva).

\begin{tabular}{lccc}
\hline Treatments/ Perlakuan & WRI & RGR $(\mathrm{g} / \mathrm{day} / \mathrm{g})$ & ECI $(\%)$ \\
\hline Control/ Kontrol & $\left.1.87 \mathrm{e}^{*}\right)$ & $0.17 \mathrm{c}$ & $15.85 \mathrm{c}$ \\
$\mathrm{F}(S)$ & $0.60 \mathrm{c}$ & $0.03 \mathrm{a}$ & $03.87 \mathrm{a}$ \\
$\mathrm{B}(H)$ & $0.40 \mathrm{~b}$ & $0.02 \mathrm{a}$ & $06.37 \mathrm{a}$ \\
$\mathrm{C}(K)$ & $0.30 \mathrm{a}$ & $0.03 \mathrm{a}$ & $05.08 \mathrm{a}$ \\
$\mathrm{F}+\mathrm{FW}(S+S M)$ & $0.97 \mathrm{~d}$ & $0.12 \mathrm{~b}$ & $10.29 \mathrm{~b}$ \\
$\mathrm{C}+\mathrm{FW}(K+S M)$ & $2.33 \mathrm{f}$ & $0.21 \mathrm{~d}$ & $12.11 \mathrm{~b}$ \\
\hline
\end{tabular}

*) Numbers followed by different letters in the same column show significant differences at $5 \%$ level according to Duncan Multiple Range Test

*) Angka yang diikuti oleh huruf yang berbeda dalam kolom yang sama menunjukkan perbedaan yang nyata berdasarkan uji jarak berganda Duncan dengan tingkat kepercayaan $5 \%$.

\section{Anatomical observation of BSF imago}

According to observation result, $\mathrm{C}+\mathrm{FW}$ treatment was chosen as the best treatment for the conversion of $\mathrm{CPH}$ and we observed the body size of the BSF's imago produced by $\mathrm{C}+\mathrm{FW}$ treatment and compared with food waste and composted $\mathrm{CPH}$ treatments as a control. In general, the result showed that the BSF's imago produced by food waste treatment as indicated as a larger body size compared to $\mathrm{C}+\mathrm{FW}$ and composted (C) treatments (Table 3). The $\mathrm{C}+\mathrm{FW}$ treatment has a significant difference in body size compared to $\mathrm{C}$ treatment and has no different in the abdomen and antenna length (3.04 $\mathrm{mm}$ and $3.36 \mathrm{~mm}$, respectively) with food waste treatment. The body size of BSF's imago was related to ECI and weight of BSF larvae. Higher ECI value indicated a higher weight of larvae and produced bigger BSF's imago. Although the BSF mating and oviposition behavior mostly affected by an environmental condition such as temperature, humidity, and light (Booth \& Sheppard, 1984; Tomberlin et al., 2009; Tomberlin \& Sheppard, 2002; Zhang et al., 2010), the body size also affected the fecundity of insects (Knapp \& Uhnavá, 2014). It indicated that a better feed provided a better fecundity of female BSF. 
Table 3. Average body size of BSF's imago (mm):

Tabel 3. Rata-rata ukuran tubuh imago BSF (mm)-

\begin{tabular}{|c|c|c|c|c|c|c|c|c|}
\hline $\begin{array}{l}\text { Treatment/ } \\
\text { Perlakuan }\end{array}$ & $\begin{array}{l}\text { Body } \\
\text { length/ } \\
\text { Panjang } \\
\text { tubuh }\end{array}$ & $\begin{array}{c}\text { Thorax } \\
\text { length/ } \\
\text { Panjang } \\
\text { toraks }\end{array}$ & $\begin{array}{l}\text { Thorax } \\
\text { width/ } \\
\text { Lebar } \\
\text { toraks }\end{array}$ & $\begin{array}{l}\text { Abdomen } \\
\text { length/ } \\
\text { Panjang } \\
\text { abdomen }\end{array}$ & $\begin{array}{c}\text { Abdomen } \\
\text { width/ } \\
\text { Lebar } \\
\text { abdomen }\end{array}$ & $\begin{array}{l}\text { Head } \\
\text { width/ } \\
\text { Lebar } \\
\text { kepala }\end{array}$ & $\begin{array}{l}\text { Wing } \\
\text { length/ } \\
\text { Panjang } \\
\text { sayap }\end{array}$ & $\begin{array}{c}\text { Antenna } \\
\text { length/ } \\
\text { Panjang } \\
\text { antena }\end{array}$ \\
\hline $\begin{array}{l}\text { Control/ } \\
\text { Kontrol }\end{array}$ & $\left.14.53 c^{*}\right)$ & $5.03 \mathrm{c}$ & $3.59 \mathrm{c}$ & $7.34 \mathrm{~b}$ & $3.41 \mathrm{c}$ & $3.62 \mathrm{~b}$ & $11.10 \mathrm{c}$ & $3.36 \mathrm{~b}$ \\
\hline $\begin{array}{l}\mathrm{C}+\mathrm{FW} \\
(K+S M)\end{array}$ & $12.80 \mathrm{~b}$ & $4.34 \mathrm{~b}$ & $3.13 \mathrm{~b}$ & $6.86 \mathrm{~b}$ & $3.04 \mathrm{~b}$ & $3.42 \mathrm{~b}$ & $9.33 \mathrm{~b}$ & $3.36 \mathrm{~b}$ \\
\hline $\mathrm{C}(K)$ & $9.88 \mathrm{a}$ & $3.25 \mathrm{a}$ & $2.25 \mathrm{a}$ & $5.21 \mathrm{a}$ & $2.17 \mathrm{a}$ & $2.68 \mathrm{a}$ & $7.10 \mathrm{a}$ & $2.55 \mathrm{a}$ \\
\hline
\end{tabular}

*) Numbers followed by different letters in the same column show significant differences at $5 \%$ level according to Duncan Multiple Range Test

*) Angka yang diikuti oleh huruf yang berbeda dalam kolom yang sama menunjukkan perbedaan yang nyata berdasarkan uji jarak berganda Duncan dengan tingkat kepercayaan 5\%.

\section{Conclusion}

The best response on feed treatment was found in control (food waste) which was characterized by the highest of fresh weight among all treatments. However, the most ideal treatment that possible to be applied in the cocoa plantation was to mix the feed for BSF larvae with a food waste for the first 6 days and replace the feed with composted $\mathrm{CPH}$ afterwards. The bioconversion performance produced by this treatment has the closest result to the control with shorter development time. The body size of BSF's imago was related to ECI and weight of BSF larvae. Higher ECI value indicated a higher weight of larvae and also produced bigger BSF's imago.

\section{References}

Alemawor F, VP Dzogbefia, EO Oddoye \& JH Oldham (2009). Effect of Pleurotus ostreatus fermentation on cocoa pod husk composition: Influence of fermentation period and $\mathrm{Mn} \mathrm{2+}$ supplementation on the fermentation process. African Journal of Biotechnology 8(9), 19501958 .

Booth DC \& C Sheppard (1984). Oviposition of the black soldier fly, Hermetia illucens (Diptera: Stratiomyidae): eggs, masses, timing, and site characteristics. Environmental entomology 13(2), 421-423.

BPS (2017) Statistik Kakao Indonesia. Jakarta, Badan Pusat Statistik. pp. 9-11.

Cockcroft BL (2018). An evaluation of defatted black soldier fly (Hermetia illucens) larvae as a protein source for broiler chicken diets. Stellenbosch, Stellenbosch University.

Diener S, C Zurbrügg \& K Tockner (2009). Conversion of organic material by black soldier fly larvae: establishing optimal feeding rates. Waste Management Research 27(6), 603-610.
Elwert C, I Knips \& P Katz (2010). A novel protein source: maggot meal of the black soldier fly (Hermetia illucens) in broiler feed. In: Proc Tagung Schweine-und Geflügelernährung. Wittenberg, 23-25 November 2010, p140-42.

Finke MD (2013). Complete nutrient content of four species of feeder insects. Zoo biology, 32(1), 27-36.

Glazier DS (2002). Resource-allocation rules and the heritability of traits. Evolution 56(8), 16961700.

Gunawan \& C Talib (2017). Development of feed and organic fertilizer bioindustry based on cocoa-goat integration. Wartazoa 26(4), 163172.

Hou C (2014). Increasing energetic cost of biosynthesis during growth makes refeeding deleterious. The American Naturalist 184(2), 233-247.

Jayanegara A, N Yantina, B Novandri, E Laconi, N Nahrowi \& M Ridla (2017). Evaluation of some insects as potential feed ingredients for ruminants: Chemical composition, in vitro rumen fermentation and methane emissions. Journal of Indonesian Tropical Animal Agriculture 42(4), 247-254.

Knapp M \& K Uhnavá (2014). Body size and nutrition intake effects on fecundity and overwintering success in Anchomenus dorsalis (Coleoptera: Carabidae). Journal of Insect Science 14(1), 240.

Laconi EB \& A Jayanegara (2015). Improving nutritional quality of cocoa pod (Theobroma cacao) through chemical and biological treatments for ruminant feeding: in vitro and in vivo evaluation. Asian-Australasian journal of animal sciences 28(3), 343.

Lalander C, S Diener, ME Magri, C Zurbrügg, A Lindström \& B Vinnerås (2013). Faecal sludge 
management with the larvae of the black soldier fly (Hermetia illucens)-From a hygiene aspect. Science of the Total Environment 458, 312-318.

Manurung R, A Supriatna, RR Esyanthi \& RE Putra (2016). Bioconversion of rice straw waste by black soldier fly larvae (Hermetia illucens L.): Optimal feed rate for biomass production. Journal of Entomology and Zoology Studies 4(4), 1036-1041.

Müller A, D WoS \& O Gutzeit Herwig (2017). The black soldier fly, Hermetia illucens - a promising source for sustainable production of proteins, lipids and bioactive substances. In Zeitschrift für Naturforschung C, 351 .

Oonincx DG, S Van Broekhoven, A Van Huis \& JJ van Loon (2015). Feed conversion, survival and development, and composition of four insect species on diets composed of food byproducts. PLoS One 10(12), 1-20.

Rehman KU, A Rehman, M Cai, L Zheng, X Xiao, AA Somroo, H Wang, W Li, Z Yu \& J Zhang (2017). Conversion of mixtures of dairy manure and soybean curd residue by black soldier fly larvae (Hermetia illucens L.). Journal of Cleaner Production 154, 366-373.

Spranghers T, M Ottoboni, C Klootwijk, A Ovyn, S Deboosere, B De Meulenaer, J Michiels, M Eeckhout, P De Clercq \& S De Smet (2017). Nutritional composition of black soldier fly (Hermetia illucens) prepupae reared on different organic waste substrates. Journal of the Science of Food and Agriculture 97(8), 2594-2600.

Supriyatna A, R Manurung, R Esyanthi \& RE Putra (2016). Growth of black soldier larvae fed on cassava peel wastes, An agriculture waste. Journal of Entomology and Zoology Studies, 4(6), 161-165.

Sutikno A (1997). Cocoa pod for feeding of ruminant livestock. Wartazoa 6(6), 38-43.

Tomberlin JK, PH Adler \& HM Myers (2009). Development of the black soldier fly (Diptera: Stratiomyidae) in relation to temperature. Environmental Entomology, 38(3), 930-934.

Tomberlin JK \& DC Sheppard (2002). Factors influencing mating and oviposition of black soldier flies (Diptera: Stratiomyidae) in a colony. Journal of Entomological Science 37(4), 345-352.

Zhang J, L Huang, J He, JK Tomberlin, J Li, C Lei, M Sun, Z Liu \& Z Yu (2010). An artificial light source influences mating and oviposition of black soldier flies, Hermetia illucens. Journal of Insect Science, 10(1),

Zheng L, Y Hou, W Li, S Yang, Q Li \& Z Yu (2012). Biodiesel production from rice straw and restaurant waste employing black soldier fly assisted by microbes. Energy 47(1), 225229. 